\title{
Characteristics of transit tourism in Hungary with a focus on expenditure
}

Áron Kincses This study introduces the behaviour of participants Hungarian Central in transit tourism in Hungary with a focus on their Statistical Office, expenditure. With the help of multivariable Budapest, Hungary mathematical-statistical methods, the motivational

E-mail: background and the spending characteristics of aron.kincses@ksh.hu foreigners visiting Hungary between 2009 and 2013 are explored; in addition, the factors influencing expenditure, according to nationality, are

Géza Tóth investigated.

Hungarian Central

According to our investigations, people in Statistical Office, transit, whose spending is continuously increasing, Budapest, Hungary make up a significant share of the expenditure of

E-mail: foreigners arriving in Hungary. Typical types of geza.toth@ksh.hu spending during transit are fuel purchases and dining at restaurants. Among transit visitors to Hungary, Romanian, Serbian (including Monte-

Mihály Tömöri negro and Kosovo), and Bulgarian nationals have University of Nyíregyháza, the highest share. While the number and Nyíregyháza, Hungary expenditure of transit visitors slightly increased E-mail: during the examined period, the per capita spending tomori.mihaly@nye.hu

Gábor Michalkó decreased. The results of the study show that this is due to the changes in the composition of the countries involved.

HAS RCAES, largely determined by nationality. The most Corvinus University of important conclusion of our research is that the Budapest, Hungary most significant characteristics of transit depend on E-mail: general European trends (labour market conditions, michalko.gabor@csfk.mta.hu tourism supply, etc.) and conditions (visa requirements, transport infrastructure, accommo-

Keywords: dation along transit routes, among others) provided transit tourism, for transit visitors by Hungary. tourism expenditure,

Hungary 


\section{Introduction}

Tourism is one of the driving forces of world economy. The 4\% annual average growth rate of international tourist arrivals and the similar growth rate of transit visitors' expenditure positively influence the GDP, employment, and export figures of the affected countries (UNWTO 2015). In parallel with the increase in the number of visitors and their expenditure, the spectrum of the interpretation of international tourism is becoming wider. As a result, nowadays, cross-border trips lasting for less than 24 hours are also regarded as international tourism (Cooper-Hall 2016). Due to the spatiotemporal differentiation of leisure activities, the availability of cross-border services and the loosening spatial ties of working, numerous new motivations behind travelling have emerged. A considerable proportion of these motivations are realized during short or day trips (Wynen 2013, Yousuf-Backer 2015). The European Union also recognized the importance of the phenomenon, and therefore the European Parliament and the Council introduced a regulation ${ }^{1}$ in 2011 concerning the statistical measurement of trips that were not included in the previous (1995) directive. In Hungary, the Geographical Research Institute of the Hungarian Academy of Sciences (HAS), Research Centre for Astronomy and Earth Sciences (RCAES), has been conducting research since 2012 in the framework of OTKA ${ }^{2}$ on the economic, social, and environmental characteristics of trips labelled 'invisible tourism' (Michalkó-Rátz 2013). The examination of Hungary's transit tourism began within the framework of this project (in cooperation with the Hungarian Central Statistical Office); the first results contributed towards the identification of the affected destinations (Kincses et al. 2014).

\section{Theoretical background}

Despite the fact that transit has been a noteworthy phenomenon for a long time in many Central-European countries, including Austria, the Czech Republic, Hungary, Slovakia, and Slovenia (at least a quarter of incoming visitors enter and exit the given country from two different sections of the border), still, the international literature hardly discusses this issue (Bakic 1988, Johnson 1995, Hall 1998). Among the causes behind the neglect of this topic by researchers, the nature of transit should be mentioned first, since transit is a rapid form of mobility in a relatively closed system, whose observation causes numerous difficulties. The main aim of transit is to shorten idle time and reach destinations as fast as possible, that is, bridge the section (which is often an individual entity, such as a state or microstate) between the place of origin

\footnotetext{
${ }^{1}$ Regulation (EU) No 692/2011 of the European Parliament and of the Council of 6 July 2011 concerning European statistics on tourism and repealing Council Directive 95/57/EC.

${ }^{2}$ Hungarian Scientific Research Fund.
}

Regional Statistics, Vol 6, No 2. 2016: 129-148; DOI: 10.15196/RS06207 
and the destination with minimal stops and/or with the shortest possible length of stay. Therefore, data gathering concerning transit visitors, who are continuously under time pressure, is extremely difficult, as they are not willing to fill in questionnaires or answer interview questions; in addition, the service providers who contact them provide only limited information. Another possible reason behind the unrecognized potential in researching problems related to transit lies in the underestimation of the role and effects of the phenomenon. Within the group of foreigners arriving in a country, transit visitors (in relation to social, economic, and environmental effects of their one-sided activity) besides tourists and excursionists, have been hardly examined compared to their real share.

The international literature directly discussing transit primarily focuses on traffic occurring at the airports. In addition to the examination of various services available at international airports, with special regard to duty free shops (Graham 2009), various security issues, including border crossing, customs (Prager et al. 2015), and epidemiological risks (Malone et al. 2009) have been researched. It has been recognized that hub airports with favourable geographical location and significant numbers of transit passengers profit not only from the special demand of transit passengers staying at airport hotels but also from dynamic tourism development built upon the attractiveness of cities (Lohmann et al. 2009).

Studies dealing with transit indirectly are concerned with transportation and environmental issues, among other things. The assessment of the role of transportation companies in contributing to successful transit management (Schiefelbusch et al. 2007) and the contribution of the private sector (GopalanNarayan 2010) are among these research topics. In the latter case, neither the role of the informal (Michaud 1991) nor the sharing economy (Böhler et al. 2006) can be neglected in the process of understanding transit. The support services provided by local communities are crucial for reaching the inaccessible destinations of the third world and crossing areas with poor transport infrastructure. Environmental pollution associated with transit and ensuring the implementation of the sustainability principle along the affected routes are important (Filimonau et al. 2014) research areas.

Exploration of the travelling habits and tourism behaviour of transit visitors is seldom discussed in the literature. Within the topic of transit, hitchhiking (Laviolette 2016) represents a special field, which is, on the one hand, a lifestyle, and on the other hand, a phenomenon on the periphery of the sharing economy and the manifestation of social responsibility and solidarity at the same time. While the effects of hitchhiking in transit are indeed marginal, the behaviour of visitors arriving by caravans or motorhomes can be examined in the context of 'traditional' tourism as well. Due to the freedom and flexibility provided by caravans and/or motorhomes, it is not unusual for the motivation of transit to be coupled with an overnight stay at the destination (Green 1978). This can be planned (calculated), spontaneous (passengers get attracted to the place where they stopped), or can occur due to compulsion and

Regional Statistics, Vol 6, No 2. 2016: 129-148; DOI: 10.15196/RS06207 
other circumstances (unexpected events, traffic jam, etc.). The use of the caravan and/or motorhome (toll, parking fee, fuel), and its potential repair, passengers' consumption (retailing, catering), leisure activities, or overnight stay can already generate substantial spending.

Transit is not registered in the framework of accommodation statistics, since in most cases it is not coupled with an overnight stay in the given country (Parroco et al. 2012). In most EU countries belonging to the Schengen Area, the flow of EU citizens is not registered, thus this phenomenon is assessed by estimations, derived data, or data coming from statistical sampling (Volo-Giambalvo 2008). The international literature uses the terms unobserved or unmeasured tourism concerning mobility related to transit passenger traffic (De Cantis et al. 2015), while the Hungarian literature describes trips lasting for less than 24 hours and/or without overnight stay at registered accommodation as invisible tourism (Michalkó-Rátz 2013).

Spending is the most vital element of tourist behaviour (Rátz 2004). Spending makes a traveller become a tourist, and the use of paid services involves the visitor in tourism. Expenditure correlates with many factors determining travel, and the strongest correlation of expenditure is observed with motivation (Suh-McAvoy 2005). Within the structure of an average tourist's spending, the costs of accommodation, catering, events, and shopping have roughly the same share (Michalkó 2012).

\section{Method}

The Hungarian Central Statistical Office has been measuring transit visitors to Hungary since 2007 as part of the questionnaire called 'Foreigners' tourism-related and other expenditures (quarterly)'. The survey covers foreigners leaving and Hungarians entering Hungary by any vehicle, except for lorry. The study uses nonprobabilistic and structured sample. Since 2008, the yearly sample size has been approximately 60,000, of which, the sample of transit visitors has been around 14,000 or 15,000. The selection of days is systematic and random. Data are collected through personal interviews.

In our research, five years' data were examined. The basic reason behind the selection of the period between 2009 and 2013 is that data of the period after the economic crisis clearly differs from the preceding period. From 2009, however, it can be detected how data on transit reflects economic recovery.

\section{Characteristics of foreign tourists}

Foreign tourists' spending in Hungary can be categorized according to the types of spending motivations and nationalities. Tourists' spending in Hungary was increasing

Regional Statistics, Vol 6, No 2. 2016: 129-148; DOI: 10.15196/RS06207 
slowly, but continuously. During the examined five-year period, tourists' spending rose by $6 \%$. The highest tourists' expenditure categories include 'shopping for souvenirs' and 'accommodation with catering'. From 2009 to 2013, the most dynamic increase in expenditures was observed in the following categories: transportation $(205 \%)$, cultural programmes (192\%), entertainment (177\%), and medical treatment $(173 \%)$.

Figure 1

Total spending of tourists by type of spending

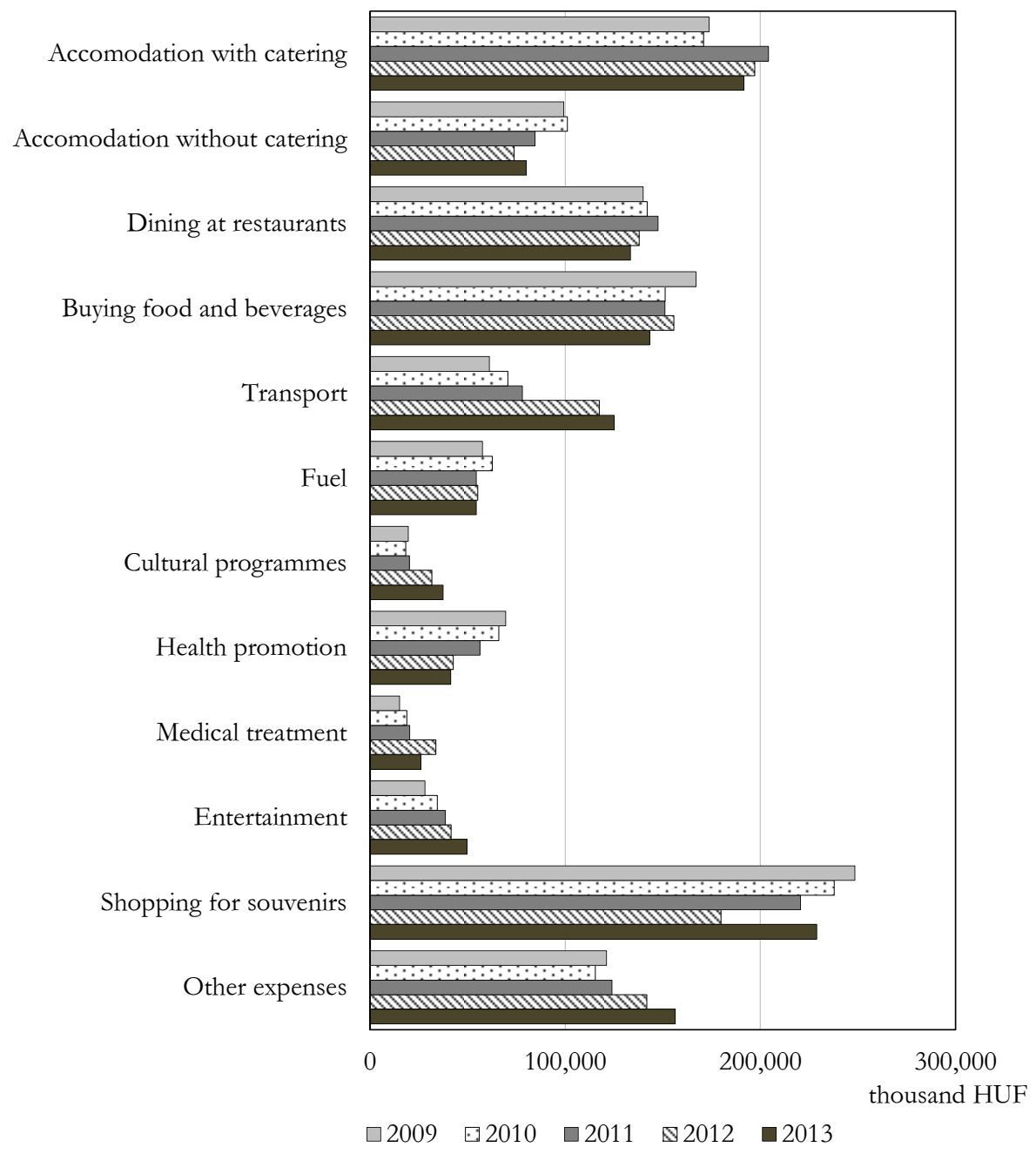

Besides the types of spending, expenditures can also be categorized according to travel motivations.

Regional Statistics, Vol 6, No 2. 2016: 129-148; DOI: 10.15196/RS06207 
Figure 2

The distribution of spending of all tourists, according to their motivations

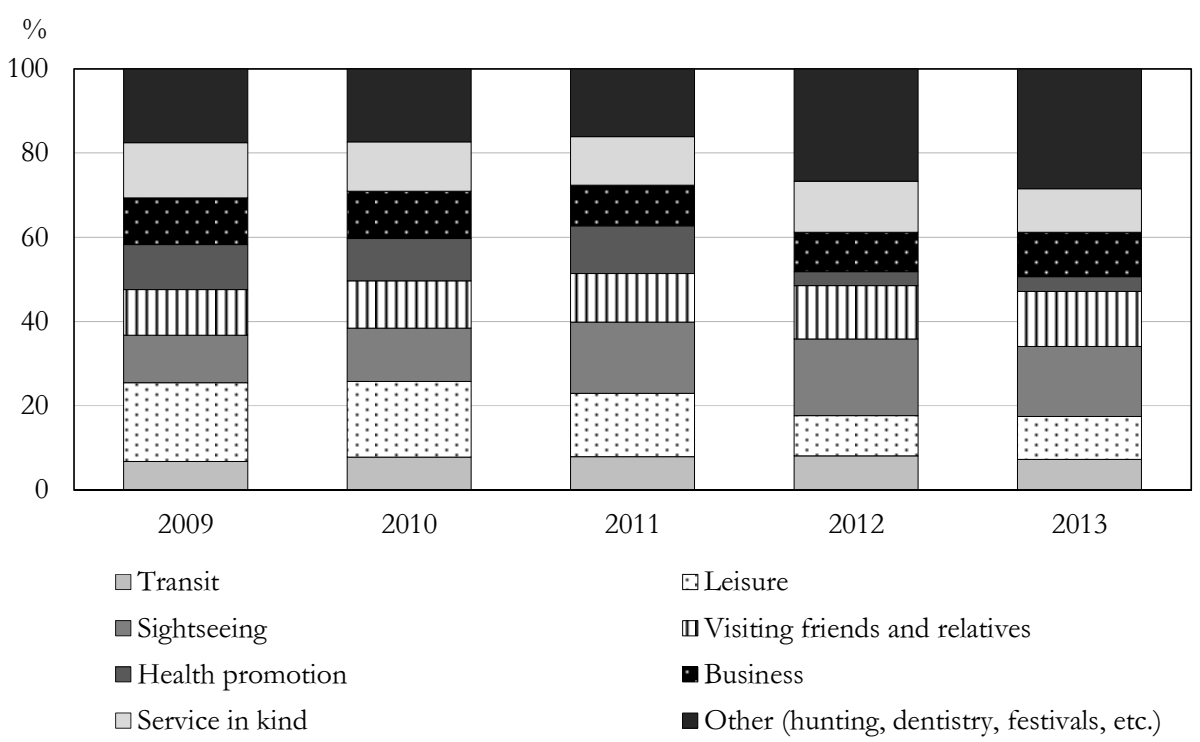

City tours (sightseeing) and visiting friends and relatives are the most important motivations of foreign tourists in Hungary. During the examined five-year period, the share of motivations of foreign tourists' spending (denominated in Hungarian forints) changed significantly. Traditional motivations (such as health promotion and leisure) lost ground, while the proportion of and the sum spent on hunting, dentistry, and sightseeing increased continually and dynamically.

Figure 3

\section{The share of tourism motivations of total spending and its changes}

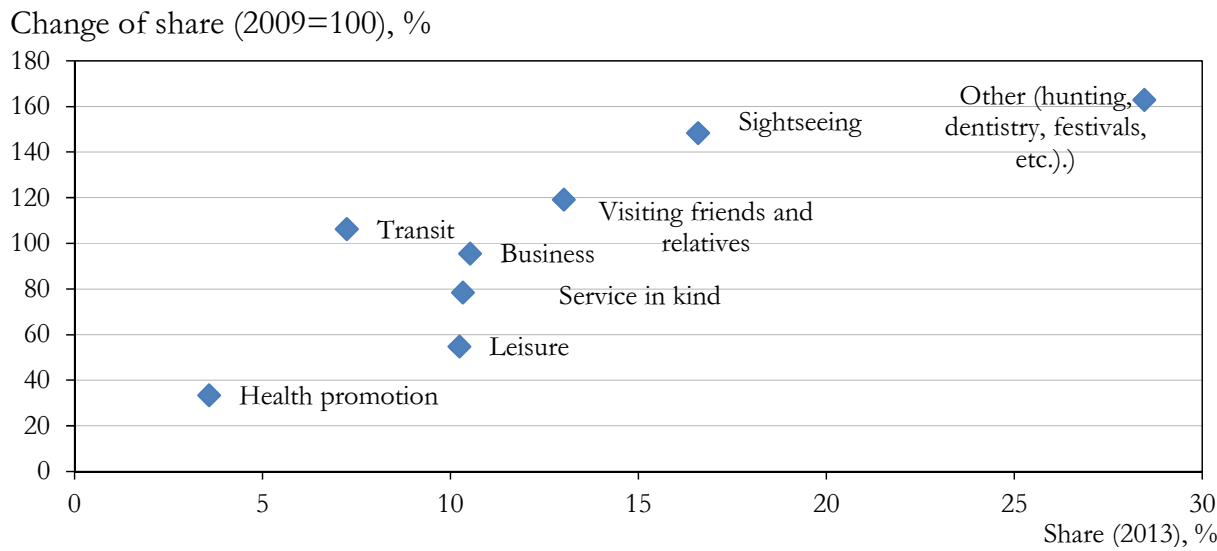

Regional Statistics, Vol 6, No 2. 2016: 129-148; DOI: 10.15196/RS06207 
Motivation and the type of spending are interconnected. The strength indicators measure the strength of the correlation between qualitative variables. The basic concept of association analysis is that the expected frequency is calculated assuming the independence of variables in every pair. The contingency table displays crosscorrelations and the frequency distribution of the variables.

Table 1

\section{Cross-correlations}

\begin{tabular}{|c|c|c|c|}
\hline & $\mathrm{x}_{1}$ & $\mathrm{x}_{2}$ & $\sum$ \\
\hline $\mathrm{y}_{1}$ & $\mathrm{p}_{11}$ & $\mathrm{p}_{12}$ & $\mathrm{p}_{1 .}$ \\
\hline $\mathrm{y}_{2}$ & $\mathrm{p}_{21}$ & $\mathrm{p}_{22}$ & $\mathrm{p}_{2 .}$ \\
\hline$\Sigma$ & $\mathrm{p}_{1}$ & $\mathrm{p}_{2}$ & 1 \\
\hline
\end{tabular}

Let us consider a $2 \mathrm{x} 2$ table (non-symmetric), where $\mathrm{pij}=\mathrm{P}(\mathrm{X}=\mathrm{xi}, \mathrm{Y}=\mathrm{yj}), \mathrm{i}, \mathrm{j}=1,2$. In this case, the independence of the two variables is measured by:

$$
\Phi^{2}=\sum_{i=1}^{I} \sum_{j=1}^{J} \frac{\left(p_{i j}-p_{i .} \cdot p_{j .}\right)^{2}}{p_{i .} \cdot p_{j .}}
$$

- By the normalization of $\boldsymbol{\Phi}^{2}$, we get Pearson's correlation:

$$
P=\sqrt{\frac{\Phi^{2}}{\Phi^{2}+1}}
$$

- $\mathrm{P}=0 \quad$ independence

- $\mathrm{P}=1 \quad$ functional

- $0 \leq \mathrm{P} \leq 1$ stochastic relationship

Table 2

Strength of relationships between foreigners' spending and travel motivations

\begin{tabular}{c|c|c|c}
\hline Year & $\phi^{2}$ & $\mathrm{P}$ & $\begin{array}{c}\text { Proportion of transit of } \\
\phi^{2}, \%\end{array}$ \\
\hline 2009 & 0.755 & 0.656 & 17.177 \\
2010 & 0.734 & 0.651 & 17.065 \\
2011 & 0.696 & 0.641 & 19.690 \\
2012 & 0.611 & 0.616 & 21.363 \\
2013 & 0.571 & 0.603 & 24.335
\end{tabular}

There is a moderate, although continuously weakening, relationship between foreigners' spending and travel motivations. While the value of Pearson's correlation coefficient decreased by $5 \%$ during the examined five-year period, the dependence of the types of spending and transit increased further. This means that typical types of spending, while this is not true of other travel motivations, characterize transit.

Regional Statistics, Vol 6, No 2. 2016: 129-148; DOI: 10.15196/RS06207 
The share of transit visitors' spending accounts for 49\% and 14\% of foreigners' total expenditure on fuel and dining at restaurants, respectively, while they do not spend on health promotion, cultural programmes, or medical treatment.

\section{The role of transit in Hungary's inbound tourism}

In 2013, approximately 15,563 thousand transit visitors arrived in Hungary, and their expenditure was 91,914 million forints. From 2009 to 2013, the number of visitors increased by $6 \%$, while their expenditure grew by $12 \%$ at current prices. As compared to the base year and the number of all visitors, the number of transit visitors rose one percentage point slower, while their expenditure surged six percentage points faster.

\section{The number of foreign transit visitors to Hungary and their total expenditure $(2009=100 \%)$}

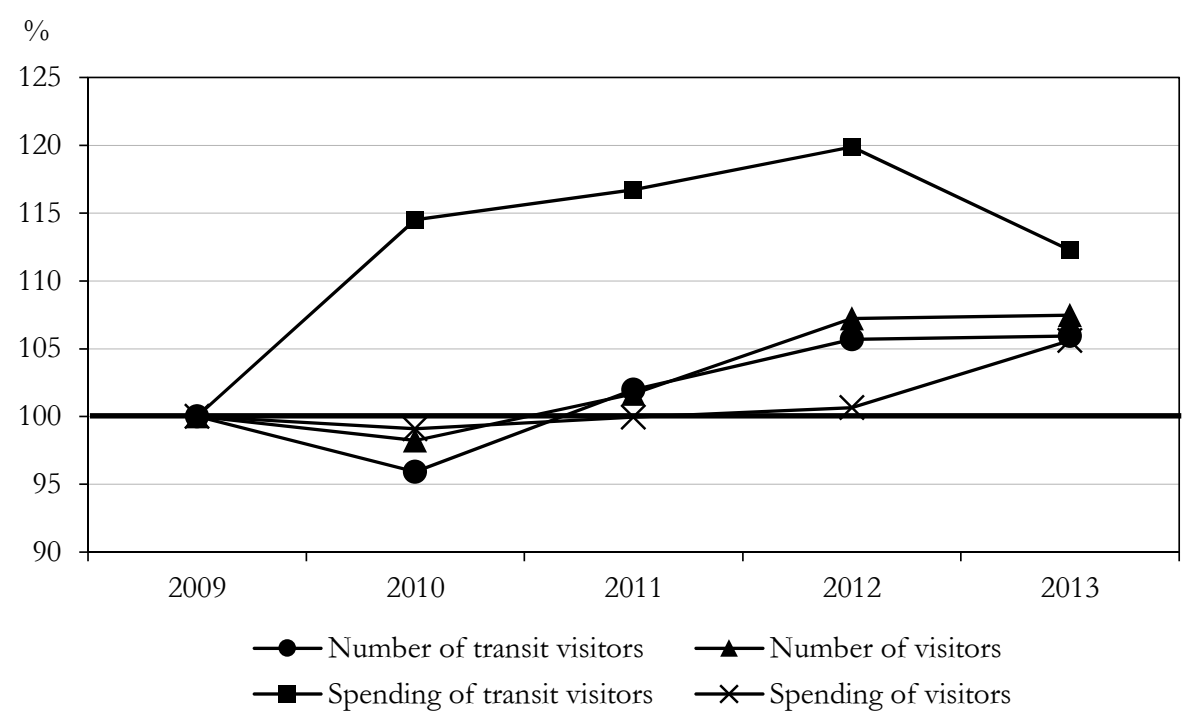

As shown in tables 3 and 4, transit visitors to Hungary between 2009 and 2013 accounted for more than a third of foreigners arriving in Hungary. The share of the length of stay and expenditure of these transit visitors was $15-16 \%$ and $7-8 \%$, respectively, which showed only minimal fluctuations from year to year. The per capita spending of transit visitors reached $18-20 \%$ of the total expenditure of foreign visitors during the period. The average length of stay, due to the nature of the activity, was 'only' one day, although there was a slight increase. 
Share of transit visitors of foreign visitors' total number, length of stay, and expenditure in Hungary

\begin{tabular}{c|c|c|c}
\hline Year & Visitors & Length of stay & Expenditure \\
\hline 2009 & 36.2 & 15.6 & 6.8 \\
2010 & 35.3 & 15.4 & 7.9 \\
2011 & 36.3 & 16.0 & 8.0 \\
2012 & 35.6 & 16.6 & 8.1 \\
2013 & 35.6 & 16.2 & 7.2
\end{tabular}

Table 4

Comparison of transit and foreign visitors' total expenditure and length of stay

\begin{tabular}{c|c|c|c|c}
\hline \multirow{2}{*}{ Year } & \multicolumn{2}{|c|}{$\begin{array}{c}\text { Per capita expenditure, thousand } \\
\text { forints }\end{array}$} & \multicolumn{2}{c}{ Average length of stay, days } \\
\cline { 2 - 5 } & Transit & total & Transit & Total \\
\hline 2009 & 5.6 & 29.6 & 1.03 & 2.39 \\
2010 & 6.7 & 29.8 & 1.05 & 2.40 \\
2011 & 6.4 & 29.1 & 1.06 & 2.40 \\
2012 & 6.3 & 27.7 & 1.07 & 2.29 \\
2013 & 5.9 & 29.0 & 1.06 & 2.33
\end{tabular}

\section{Transit tourism according to nationality}

Transit visitors' country of origin was analysed according to 2013 data. Our analysis took into account only the countries whose sample size is above 100 , therefore related results are statistically relevant.

The impact of transit tourism, due to its nature, can only be identified within a limited geographical distance. Therefore, it is primarily the expenditure of tourists from Europe and especially from countries near Hungary that can be detected.

Concerning the frequency, length of stay, and spending of transit visitors to Hungary, the nationals of Romania, Serbia (together with Montenegro and Kosovo), and Bulgaria stand out. These three countries account for more than half the number, length of stay, and expenditure of transit visitors to Hungary. The average length of stay is the longest in the case of Italian, German, and Bulgarian nationals. There is an increasing tendency among these nationals (apparently because of the length of the journey) to break their journey and resume it after an overnight stay at an accommodation establishment. 
The per capita expenditure is the highest among the Ukrainian nationals, followed by the Italians and Germans.

Table 5

Major characteristics of transit visitors to Hungary according to nationality, 2013

\begin{tabular}{l|r|r|r|c|c}
\hline \multirow{2}{*}{ Country } & \multicolumn{3}{|c|}{ Share (\%) } & $\begin{array}{c}\text { Average } \\
\text { ength of stay, } \\
\text { days }\end{array}$ & $\begin{array}{c}\text { Per capita } \\
\text { expenditure, } \\
\text { thousand } \\
\text { forints }\end{array}$ \\
\cline { 2 - 5 } Total & visitors & length of stay & expenditure & 1.06 & 5.91 \\
of which: & 100.0 & 100.0 & 100.0 & 1.02 & 4.67 \\
Austria & 4.7 & 4.6 & 3.7 & 1.09 & 7.25 \\
Bulgaria & 7.2 & 7.4 & 8.8 & 1.07 & 5.57 \\
Czech Republic & 3.3 & 3.4 & 3.2 & 1.08 & 7.04 \\
Netherlands & 0.6 & 0.6 & 0.7 & 1.00 & 3.33 \\
Croatia & 2.6 & 2.4 & 1.5 & 1.04 & 5.24 \\
Poland & 7.3 & 7.2 & 6.4 & 1.12 & 7.85 \\
Germany & 5.5 & 5.8 & 7.3 & 1.13 & 9.23 \\
Italy & 1.5 & 1.6 & 2.3 & 1.07 & 5.92 \\
Romania & 32.5 & 33.0 & 32.6 & 1.03 & 4.99 \\
Serbiaa) & 13.6 & 13.3 & 11.5 & 1.01 & 3.78 \\
Slovakia & 5.2 & 4.9 & 3.3 & 1.00 & 2.44 \\
Slovenia & 1.1 & 1.1 & 0.5 & 1.08 & 9.61 \\
Ukraine & 5.1 & 5.2 & 8.3 & &
\end{tabular}

a) Together with Montenegro and Kosovo.

Naturally, the most important part of transit visitors' expenditure is fuel costs, which accounts for $30 \%$ of their spending. It is followed by the category 'dining at restaurants' that makes up approximately $20 \%$ of the expenditure, while 'buying food and beverages' represents a slightly smaller proportion. Additional important expenditure categories include 'other expenses' and 'shopping for souvenirs'. 
Table 6

Shares of the main spending types of transit visitors' total spending, 2013

\begin{tabular}{l|c|c|c|c|c|c}
\hline \multicolumn{1}{c|}{ Country } & $\begin{array}{c}\text { Accommodation } \\
\text { with catering }\end{array}$ & $\begin{array}{c}\text { Dining at } \\
\text { restaurants }\end{array}$ & $\begin{array}{c}\text { Buying } \\
\text { food and } \\
\text { beverages }\end{array}$ & Fuel & $\begin{array}{c}\text { Shopping } \\
\text { for } \\
\text { Souvenirs }\end{array}$ & $\begin{array}{c}\text { Other } \\
\text { expenses }\end{array}$ \\
\hline Austria & 2.7 & 20.1 & 12.6 & 30.8 & 21.9 & 10.1 \\
Bulgaria & 3.4 & 18.5 & 12.7 & 39.6 & 8.5 & 14.7 \\
Czech Republic & 6.0 & 21.9 & 11.7 & 36.9 & 5.1 & 15.6 \\
Netherlands & 5.3 & 20.8 & 14.2 & 33.7 & 20.2 & 5.5 \\
Croatia & 0.0 & 20.8 & 19.6 & 23.2 & 6.0 & 28.2 \\
Serbiaa) & 1.8 & 20.4 & 19.9 & 26.1 & 15.8 & 11.8 \\
Poland & 3.6 & 21.9 & 12.3 & 38.9 & 6.0 & 14.0 \\
Germany & 6.1 & 22.7 & 12.0 & 31.7 & 14.1 & 10.9 \\
Italy & 6.1 & 23.0 & 11.3 & 31.2 & 16.6 & 11.5 \\
Romania & 3.3 & 18.5 & 20.5 & 23.7 & 13.5 & 19.2 \\
Slovakia & 1.1 & 18.0 & 11.3 & 40.4 & 6.0 & 21.6 \\
Slovenia & 0.0 & 25.5 & 14.3 & 26.2 & 7.9 & 23.0 \\
Ukraine & 2.0 & 24.4 & 22.5 & 21.9 & 12.0 & 12.7 \\
\hline \multicolumn{1}{c|}{ Average } & 3.2 & 20.2 & 17.3 & 28.8 & 12.4 & 15.6
\end{tabular}

a) Together with Montenegro and Kosovo.

Table 7

Number and expenditure of transit visitors according to the countries of origin

\begin{tabular}{|c|c|c|c|c|c|c|}
\hline \multirow[b]{2}{*}{ Country } & \multicolumn{3}{|c|}{2009} & \multicolumn{3}{|c|}{2013} \\
\hline & visitors (B0) & $\begin{array}{l}\text { expenditure, } \\
\text { thousand } \\
\text { forints }(\mathrm{A} 0)\end{array}$ & $\begin{array}{c}\text { per capita } \\
\text { expenditure, } \\
\text { thousand } \\
\text { forints } \\
(\mathrm{V} 0)\end{array}$ & $\begin{array}{l}\text { visitors } \\
\text { (B1) }\end{array}$ & $\begin{array}{c}\text { expenditure, } \\
\text { thousand } \\
\text { forints (A1) }\end{array}$ & $\begin{array}{l}\text { per capita } \\
\text { expenditure, } \\
\text { thousand } \\
\text { forints } \\
\text { (V1) }\end{array}$ \\
\hline Austria & 610,150 & $4,722,363$ & 7.74 & 737,167 & $3,442,160$ & 4.67 \\
\hline Bulgaria & - & & - & $1,118,328$ & $8,107,816$ & 7.25 \\
\hline Czech Republic & 656,343 & $2,397,038$ & 3.65 & 521,254 & $2,904,563$ & 5.57 \\
\hline Netherlands & 115,411 & 773,133 & 6.70 & 90,672 & 638,031 & 7.04 \\
\hline Croatia & 328,784 & $2,247,046$ & 6.83 & 400,621 & $1,335,655$ & 3.33 \\
\hline Poland & 914,063 & $4,580,746$ & 5.01 & $1,130,210$ & $5,926,767$ & 5.24 \\
\hline Germany & 970,348 & $6,623,624$ & 6.83 & 853,517 & $6,698,591$ & 7.85 \\
\hline Italy & 252,584 & $1,590,964$ & 6.30 & 233,682 & $2,155,759$ & 9.23 \\
\hline Romania & $5,424,806$ & $25,303,358$ & 4.66 & $5,065,355$ & $29,988,409$ & 5.92 \\
\hline Serbia ${ }^{a}$ & $1,140,318$ & $8,620,381$ & 7.56 & $2,122,500$ & $10,591,261$ & 4.99 \\
\hline Slovakia & $1,050,741$ & $2,988,138$ & 2.84 & 802,685 & $3,034,746$ & 3.78 \\
\hline Slovenia & 146,487 & 381,116 & 2.60 & 176,038 & 429,404 & 2.44 \\
\hline Ukraine & 618,018 & $5,435,836$ & 8.80 & 791,861 & $7,609,932$ & 9.61 \\
\hline Other & $2,463,683$ & $16,207,534$ & 6.58 & $1,519,312$ & $9,050,732$ & 5.96 \\
\hline Total & $14,691,736$ & $81,871,277$ & 5.57 & $15,563,202$ & $91,913,827$ & 5.91 \\
\hline
\end{tabular}

a) Together with Montenegro.

Regional Statistics, Vol 6, No 2. 2016: 129-148; DOI: 10.15196/RS06207 
By 2013, the number and expenditure of transit visitors had slightly increased as compared to 2009. Meanwhile, the per capita spending had increased from 5.57 thousand forints to 5.91 thousand forints.

The structure of Hungary's transit tourism is further analysed using the grand mean, part average, and composition effect indices.

The following marks are used:

$$
I^{\prime}=\frac{\sum B_{j 1} V_{j 1}}{\sum B_{j 1}}: \frac{\sum B_{j 1} V_{j 0}}{\sum B_{j 1}}=\frac{\sum B_{j 1} V_{j 1}}{\sum B_{j 1} V_{j 0}}
$$

$I^{\prime \prime}=\frac{\sum B_{j 1} V_{j 0}}{\sum B_{j 1}}: \frac{\sum B_{j 0} V_{j 0}}{\sum B_{j 0}}$

$I=\bar{V}_{1}: \bar{V}_{0}=\frac{\sum A_{j 1}}{\sum B_{j 1}}: \frac{\sum A_{j 0}}{\sum B_{j 0}}==\frac{\sum A_{j 1}}{\sum A_{j 0}}: \frac{\sum B_{j 1}}{\sum B_{j 0}}=\frac{\sum B_{j 1} V_{j 1}}{\sum B_{j 1}}: \frac{\sum B_{j 0} V_{j 0}}{\sum B_{j 0}}$

According to the analysis, change in part ratios has a positive effect on expenditures, while a change in the composition, change in the composition of the subpopulation (changes in the composition of countries), has a negative effect on the grand mean.

$\mathrm{I}=105.98$

$I^{\prime}=110.36$

I" $=96.04$

The changes in the structure of spending were further examined by shift-share analysis. There is a large body of literature on this method, wherein numerous examples of applications in the field of tourism can be found (Houston 1967, Stevens-Moore 1980, Selting-Loveridge 1992, Andrikopolous-Carvalho 1990, Fuchs et al. 2000, Sirakaya et al. 2002, Toh et al. 2004, Yasin et al. 2004). Our research was based on these works, and hence the detailed description of the method and its various application possibilities are disregarded.

In the following section, a shift-share analysis is applied to examine the extent to which the structure of spending of all transit visitors explains the changes in expenditures from 2010 to 2013 and the extent to which other factors, which are only the characteristics of a given country, play a role.

From 2010 to 2013, the average spending of transit visitors from the examined countries grew by 1.03 times at current prices. In the 'total change' column of Table 8,100 can be seen in the case of those countries where the change was bigger than average, while -100 is displayed where the change was smaller than average. This change can be split into two elements. The spatial (geographical) component shows the role of individual processes, concerning particular countries, in the total change. The structural (related to spending) component describes the importance of types of spending within the changes in total expenditures, with respect to the all the examined countries.

Regional Statistics, Vol 6, No 2. 2016: 129-148; DOI: 10.15196/RS06207 
It can be concluded that the component related to particular countries plays a greater role than the structural element, since in absolute values the figures for the former are higher.

Table 8

Components of the changes in spending, 2010-2013

\begin{tabular}{l|c|c|c}
\hline \multicolumn{1}{c|}{ Country } & Total change & Spatial (geographical) & Structural (spending) \\
\hline Austria & -100.0 & $-11,696.3$ & $11,596.3$ \\
Czech Republic & 100.0 & 100.5 & -0.5 \\
Croatia & -100.0 & -101.5 & 1.5 \\
Poland & 100.0 & 101.5 & -1.5 \\
Germany & -100.0 & -152.9 & 52.9 \\
Italy & 100.0 & 24.9 & 75.1 \\
Romania & -100.0 & -78.3 & -21.7 \\
Serbia) & 100.0 & 91.5 & 8.5 \\
Slovakia & -100.0 & $1,119.9$ & $-1,219.9$ \\
Slovenia & -100.0 & -97.8 & -2.2 \\
Ukraine & 100.0 & 106.4 & -6.4
\end{tabular}

a) Together with Montenegro and Kosovo.

Table 9 shows that the changes in expenditures between 2010 and 2013 primarily affected transit visitors from Serbia (along with Montenegro and Kosovo), followed by visitors from Ukraine and Poland. The nationals of Romania, Germany, and Croatia experienced a smaller change than the average. The positive and negative role of the spatial component can be highlighted in the case of countries that have already been mentioned with respect to total change. The structure of spending changed greater than the average, especially in the case of visitors from Germany, Serbia (along with Montenegro and Kosovo), and Italy, while the change was smaller in the case of Romania, Slovakia, and Ukraine.

Components of the changes in spending, 2010-2013

Table 9

\begin{tabular}{l|r|r|r|r|r|r}
\hline \multicolumn{1}{c|}{ Country } & Total+ & Total- & Spatial+ & Spatial- & Structural+ & Structural- \\
\hline Austria & 0.0 & 0.0 & 0.0 & 1.2 & 6.7 & 0.0 \\
Czech Republic & 12.0 & 0.0 & 12.4 & 0.0 & 0.0 & 0.3 \\
Croatia & 0.0 & 17.0 & 0.0 & 17.7 & 1.5 & 0.0 \\
Poland & 16.7 & 0.0 & 17.5 & 0.0 & 0.0 & 1.5 \\
Germany & 0.0 & 18.1 & 0.0 & 28.5 & 54.6 & 0.0 \\
Italy & 3.7 & 0.0 & 0.9 & 0.0 & 15.6 & 0.0 \\
Romania & 0.0 & 62.2 & 0.0 & 50.0 & 0.0 & 76.9 \\
Serbia ${ }^{\text {a }}$ & 44.7 & 0.0 & 42.0 & 0.0 & 21.6 & 0.0 \\
Slovakia & 0.0 & 0.2 & 2.1 & 0.0 & 0.0 & 12.6 \\
Slovenia & 0.0 & 2.5 & 0.0 & 2.6 & 0.0 & 0.3 \\
Ukraine & 23.0 & 0.0 & 25.1 & 0.0 & 0.0 & 8.4 \\
\hline & 100.0 & 100.0 & 100.0 & 100.0 & 100.0 & 100.0
\end{tabular}

a) Together with Montenegro and Kosovo.

Regional Statistics, Vol 6, No 2. 2016: 129-148; DOI: 10.15196/RS06207 
Table 10

Grouping of countries according to the components of changes in spending, 2010-2013

\begin{tabular}{l|l|l|l}
\hline $\begin{array}{c}\text { Spatial+ and } \\
\text { structural+ }\end{array}$ & \multicolumn{1}{|c|}{$\begin{array}{c}\text { Spatial+ and } \\
\text { structural- }\end{array}$} & $\begin{array}{c}\text { Spatial-and } \\
\text { structural+ }\end{array}$ & $\begin{array}{c}\text { Spatial-and } \\
\text { structural- }\end{array}$ \\
\hline $\begin{array}{l}\text { Italy } \\
\left.\text { Serbia }{ }^{a}\right)\end{array}$ & $\begin{array}{l}\text { Czech Republic } \\
\text { Poland }\end{array}$ & Austria & Romania \\
& Clovakia & Germany & Slovenia \\
& Ukraine & &
\end{tabular}

a) Together with Montenegro and Kosovo.

Following the analysis of the changes in expenditures, the role of nationwide processes, seasonality, quarterly data, and country specific processes in the changes of the number of visitors and their expenditure form 2009 to 2013 was examined. It was concluded that, with respect to the number of transit visitors and their spending, the most important factor during the examined period was the general tendency characterizing Hungary's average transit traffic. It implies that the most important processes of transit do not depend on the quarterly structure of transit visitors or on a country specific factor; instead, they are closely related to general European tendencies (such as labour market conditions and tourism supply), and conditions (such as visa requirements, transport infrastructure, and accommodation along transit routes) provided for them by Hungary.

Factors in the changes in the number of transit visitors to Hungary, 2009-2013

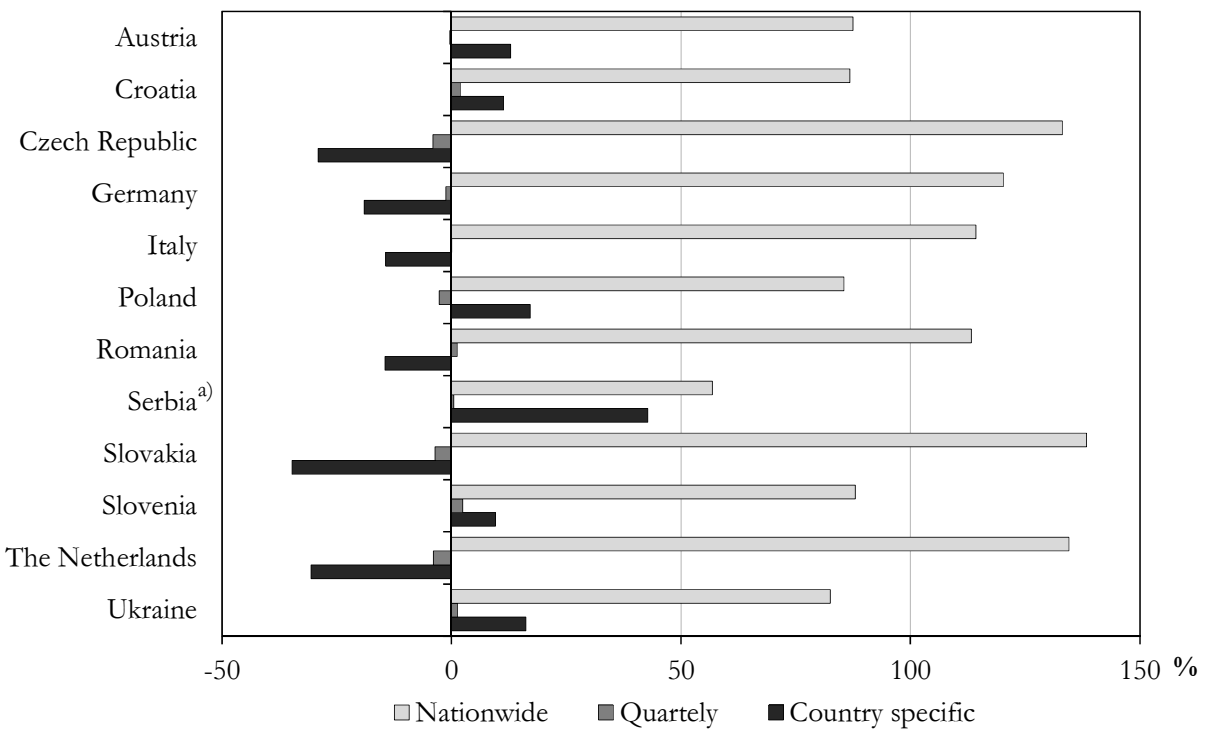

a) Together with Montenegro and Kosovo. 
The effect of the quarterly structure, the quarterly distributions, on the change in the number of visitors is marginal, while its impact on the change in expenditures is more significant. While this factor has positive values in some countries in case of the number of visitors, the value is negative in all the cases related to expenditure. This shows that the rate of increase from quarter to quarter was frequently below the yearly average, between 2009 and 2013. The country specific factors influenced the number of visitors and their expenditures both positively and negatively, even though tendencies were determined by nationwide processes. The role of country specific factors in influencing the number of visitors is somewhat greater than in the case of expenditures.

Figure 6

Factors in the changes in the expenditure of transit visitors to Hungary, 2009-2013

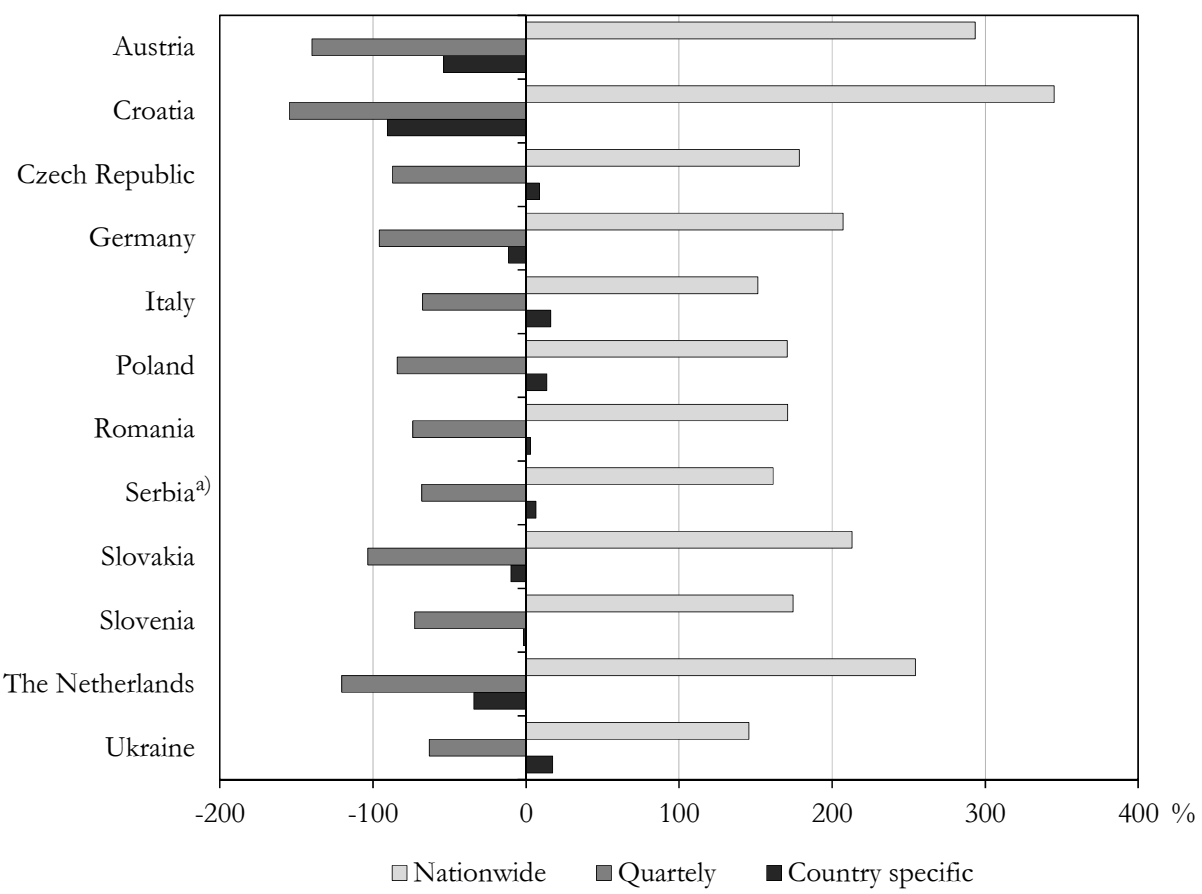

a) Together with Montenegro and Kosovo.

The extent to which per capita spending depends on the time (quarterly distribution) of transit and on nationality was also examined. In the revenue surplus/deficit column of Table 11, a value of 100 is assigned to countries whose per capita spending is higher than the average of the examined countries in 2013, whereas -100 is assigned to countries whose per capita income is below the average of the countries examined during the period. It can be concluded that per capita spending is 
primarily determined by the visitor's country of origin. This is supported by the fact that the spatial/geographical factor is more important in absolute value than the quarterly structure.

Table 11

Revenue surplus/deficit and its components among transit visitors, 2013

\begin{tabular}{l|r|r|r}
\hline \multicolumn{1}{c|}{ Country } & $\begin{array}{c}\text { Revenue- } \\
\text { surplus/deficit }\end{array}$ & Spatial & Quarterly \\
\hline Austria & -100.0 & -101.1 & 1.1 \\
Bulgaria & 100.0 & 90.7 & 9.3 \\
Czech Republic & -100.0 & -18.5 & -81.5 \\
Netherlands & 100.0 & 125.0 & -25.0 \\
Croatia & -100.0 & -103.8 & 3.8 \\
Poland & -100.0 & -60.1 & -39.9 \\
Germany & 100.0 & 103.9 & -3.9 \\
Italy & 100.0 & 99.4 & 0.6 \\
Romania & 100.0 & -263.1 & 363.1 \\
Serbiaa) & -100.0 & -104.5 & 4.5 \\
Slovakia & -100.0 & -90.0 & -10.0 \\
Slovenia & -100.0 & -100.3 & 0.3 \\
Ukraine & 100.0 & 98.5 & 1.5
\end{tabular}

a) Together with Montenegro and Kosovo.

The per capita spending is the highest in cases of Ukrainian, German, and Bulgarian nationals. In contrast, Serbia (together with Montenegro and Kosovo), Slovakia, and Croatia are characterised by lowest per capita spending. The country specific factors explain the positive effect on per capita expenditure of transit visitors in cases of nationals of Ukraine, Germany, and Bulgaria, while this effect is negative in cases of Serbia (together with Montenegro and Kosovo), Slovakia, and Croatia. The quarterly structure, the over-representation of quarter(s), with high per capita spending is characteristic of nationals of Romania, Bulgaria, and Serbia (together with Montenegro and Kosovo). An opposite tendency is observed in cases of transit visitors to Hungary from Poland, Slovakia, and the Czech Republic. 
Table 12

\section{Revenue surplus/deficit and its components among transit visitors, 2013}

\begin{tabular}{l|c|c|c|c|c|c}
\hline \multirow{2}{*}{$\begin{array}{l}\text { Country } \\
\text { Austria }\end{array}$} & \multicolumn{2}{c|}{$\begin{array}{c}\text { The role of revenue } \\
\text { surplus/deficit }\end{array}$} & \multicolumn{2}{c|}{$\begin{array}{c}\text { The role of } \\
\text { geographical } \\
\text { distribution }\end{array}$} & \multicolumn{2}{c}{$\begin{array}{c}\text { The role of the } \\
\text { quarterly structure }\end{array}$} \\
\cline { 2 - 7 } & positive & negative & positive & negative & positive & negative \\
Bulgaria & 0.0 & 12.8 & 0.0 & 13.3 & 1.5 & 0.0 \\
Czech Republic & 21.3 & 0.0 & 19.9 & 0.0 & 20.1 & 0.0 \\
Netherlands & 0.0 & 2.4 & 0.0 & 0.5 & 0.0 & 20.0 \\
Croatia & 1.5 & 0.0 & 1.9 & 0.0 & 0.0 & 3.7 \\
Poland & 0.0 & 14.5 & 0.0 & 15.5 & 5.5 & 0.0 \\
Germany & 0.0 & 10.5 & 0.0 & 6.5 & 0.0 & 42.6 \\
Italy & 23.4 & 0.0 & 25.1 & 0.0 & 0.0 & 9.3 \\
Romania & 11.0 & 0.0 & 11.2 & 0.0 & 0.6 & 0.0 \\
Serbiaa) & 1.4 & 0.0 & 0.0 & 3.9 & 52.9 & 0.0 \\
Slovakia & 0.0 & 27.2 & 0.0 & 29.3 & 12.6 & 0.0 \\
Slovenia & 0.0 & 24.0 & 0.0 & 22.2 & 0.0 & 24.4 \\
Ukraine & 0.0 & 8.6 & 0.0 & 8.9 & 0.2 & 0.0 \\
\hline & 41.4 & 0.0 & 42.0 & 0.0 & 6.5 & 0.0 \\
\hline
\end{tabular}

a) Together with Montenegro and Kosovo.

The seasonality of transit visitors to Hungary was also examined in this study. Seasonality was quantified by the calculation of the ratio between the highest and lowest quarters. It was concluded that the degree of seasonality decreased between 2009 and 2013 in the examined countries. Concerning transit visitors, the Polish, Slovak, and Dutch nationals showed the greatest seasonality, while Bulgarian, Romanian, and Croatian nationals displayed the lowest seasonality.

Table 13

Ratios of the quarters with the highest and lowest number of visitors, 2009-2013

\begin{tabular}{l|r|r|r|r|r}
\hline \multicolumn{1}{c|}{ Country } & \multicolumn{1}{c|}{2009} & 2010 & 2011 & 2012 & 2013 \\
\hline Austria & 4.6 & 3.1 & 4.0 & 2.3 & 2.3 \\
Bulgaria & - & - & 1.7 & 1.7 & 1.4 \\
Czech Republic & 11.4 & 12.5 & 14.1 & 13.4 & 7.2 \\
Netherlands & 9.7 & 12.9 & 11.1 & 16.0 & 8.5 \\
Croatia & 1.5 & 1.5 & 1.9 & 1.2 & 1.8 \\
Poland & 11.3 & 8.7 & 11.1 & 8.0 & 9.7 \\
Germany & 3.6 & 4.7 & 3.8 & 3.7 & 3.4 \\
Italy & 2.1 & 2.3 & 2.3 & 2.7 & 2.4 \\
Romania & 1.7 & 1.7 & 1.7 & 1.7 & 1.8 \\
Serbiaa) & 1.3 & 1.8 & 2.1 & 1.9 & 2.4 \\
Slovakia & 10.5 & 11.1 & 21.5 & 9.0 & 7.4 \\
Slovenia & 1.2 & 1.7 & 133.4 & 1.7 & 2.9 \\
Ukraine & 1.7 & 1.6 & 2.6 & 1.7 & 2.0
\end{tabular}

a) Together with Montenegro and Kosovo.

Regional Statistics, Vol 6, No 2. 2016: 129-148; DOI: 10.15196/RS06207 


\section{Conclusions}

The most important objective of our research, based on the major research results of our previous study (Kincses et al. 2014), was to highlight the role of transit tourism and justify its significance by statistical examination. Our investigations undoubtedly prove that, although this research topic has been relatively neglected, the topic requires a scientific analysis. This is proved by the fact that the share of spending by transit visitors comprises a significant portion of foreigners' total spending in Hungary; in addition, the spending of these visitors is registering a continuous rise. Between 2009 and 2013, the motivations of transit visitors showed a slight change, as traditional motivations were replaced with new ones. Tourism professionals and economic policy makers should also consider these changes.

Our research has also proved that transit visitors' most important types of spending are fuel costs and dining at restaurants. The nationals of Romania, Serbia (together with Montenegro and Kosovo), and Bulgaria have the highest shares of transit visitors to Hungary. During the examined period, the number and expenditure of transit visitors slightly increased and per capita spending also increased. It was shown that the reason for this is the change in the composition of the affected countries.

Our research results show that the country of origin is a more important factor than the structure of spending for determining the change in transit visitors' expenditure. It was concluded that the most important processes of transit do not depend on the quarterly structure (distribution) of transit visitors or country specific factors, but on general European tendencies (labour market conditions, tourism supply, among others) and conditions (visa requirements, transport infrastructure, accommodation along transit routes, etc.) provided for them by Hungary. In our opinion, in following these European trends, it is necessary that all actors in Hungary's tourism make the right decisions to exploit the economic benefits of transit tourism fully and avoid its drawbacks.

\section{Acknowledgement}

The study was based on the research supported by the Hungarian Scientific Research Fund under the OTKA K 100953 project (Invisible tourism in Hungary).

\section{REFERENCES}

ANDrikopolous, A. B. J.-CARvalho, E. (1990). Shift-share analysis and the potential for predicting regional growth patterns: some evidence for the region of Quebec, Canada Growth and Change 21 (1): 1-10.

BAKIC, O. (1988): Yugoslavian tourism - strategic planning of destination product Tourism Management 9 (2): 145-151.

Regional Statistics, Vol 6, No 2. 2016: 129-148; DOI: 10.15196/RS06207 
BÖHLER, S.-GrischKat, S.-HAustein, S.-HunECKE, M. (2006): Encouraging environmentally sustainable holiday travel Transportation Research Part A: Policy and Practice 40 (8): 652-670.

CoOper, CH-HALl, M. (2016): Contemporary tourism - an international approach Goodfellow Publishers Limited, Oxford.

De Cantis, S.-Parroco, A.-Ferrante, M.-Vaccina, F. (2015): Unobserved tourism Annals of Tourism Research 50: 1-18.

FilimonaU, V.-Dickinson, J.-RobBins, D. (2014): The carbon impact of short-haul tourism: a case study of UK travel to Southern France using life cycle analysis Journal of Cleaner Production 64 (1): 628-638.

Fuchs, M.-Rijken, L.-Peters, M.-Weiermair, K. (2000): Modelling Asian incoming tourism: a shift-share approach Asia Pacific Journal of Tourism Research 5 (2): 1-10.

GOPALAN, R.-NARAYAN, B. (2010): Improving customer experience in tourism: A framework for stakeholder collaboration Socio-Economic Planning Sciences 44 (2): 100-112.

GRAHAM, A. (2009): How important are commercial revenues to today's airports? Journal of Air Transport Management 15 (3): 106-111.

GREEN, F. (1978): Recreation vehicles - a perspective Annals of Tourism Research 5 (4): 429-439.

HALL, D. (1998): Tourism development and sustainability issues in Central and South-eastern Europe Tourism Management 19 (5): 423-431.

Houston, D. B. (1967): The shift and share analysis of regional growth: a critique Southern Economic Journal 33 (4): 577-581.

JOHNSON, M. (1995): Czech and Slovak tourism - patterns, problems and prospects Tourism Management 16 (1): 21-28.

KInCSES, Á.-MichalKÓ, G.-TÓTH, G. (2014): A Magyarország átutazó forgalmában érintett települések lehatárolása Területi Statisz̧tika 54 (3): 237-252.

Laviolette, P. (2016): Why did the Anthropologist Cross the Road? Hitch-Hiking as a Stochastic Modality of Travel Ethnos 81 (3): 379-401

Lohmann, G.-Albers, S.-Koch, B.-PAvlovich, K. (2009): From hub to tourist destination - An explorative study of Singapore and Dubai's aviation-based transformation Journal of Air Transport Management 15 (5): 205-211.

Malone, J.-Brigantic, R.-Muller, G.-Gadgil, A.-Delp, W.-McMahon, B.-Lee, R. -KulESZ, J.-MiHeLIC, M. (2009): U.S. airport entry screening in response to pandemic influenza: Modeling and analysis Travel Medicine and Infectious Disease 7 (4): 181-191.

MichalKó, G. (2012): Turizmológia Akadémiai Kiadó, Budapest.

MichalkÓ, G.-RÁTZ, T. (2013): Rejtett dimenziók a Kárpát-medence turizmusában In: FRISNYÁK, S.-GÁL, A. (szerk.): Kárpát-medence: természet, társadalom, gazdaság pp. 463-476, Bocskai István Gimnázium - Nyíregyházi Főiskola Turizmus és Földrajztudományi Intézet, Szerencs - Nyíregyháza.

Michaud, A. (1991): A social anthropology of tourism in Ladakh, India Annals of Tourism Research 18 (4): 605-621.

Parroco, A.-Vaccina, F.-De Cantis, S.- Ferrante, M. (2012): Multi-destination trips and tourism statistics: empirical evidences in Sicily. Economics: The Open-Access Open-Assessment E-Journal 6 (2012-44): 1-27.

Regional Statistics, Vol 6, No 2. 2016: 129-148; DOI: 10.15196/RS06207 
Prager, F.-Rose, A.-Wei, D.-Roberts, B.-Baschnagel, Ch. (2015): Economy-wide impacts of reduced wait times at U.S. international airports Research in Transportation Business \& Management 16: 112-120.

RÁTZ, T. (2004): European Tourism Kodolányi János Főiskola, Székesfehérvár.

Schiefelbusch, M.-JAin, A.-Schafer, T.-MÜller, D. (2007): Transport and tourism: roadmap to integrated planning developing and assessing integrated travel chains Journal of Transport Geography 15 (2): 94-103.

Selting, A. C.-Loveridge, S. (1992): A summary of the literature on shift-share analysis Department of Agricultural and Applied Economics, University of Minnesota College of Agriculture St. Paul, Minnesota USA.

SiRAKAYA, E.-ChOI, H. S.-VAR, T. (2002). Shift-share analysis in tourism: examination of tourism development change in a region Tourism Economics 8 (3): 303-324

STEVEns, B. H.-MoOre, C. L. (1980): A critical review of the literature on shift-share as a forecasting technique Journal of Regional Science 20 (4): 419-437.

SuH, Y.-McAvoy, L. (2005): Preferences and trip expenditures - a conjoint analysis of visitors to Seoul, Korea Tourism Management 26 (3): 325-333.

TOH, R. S.-KHAN, H.-LIM, L. L. (2004). Two-stage shift-share analyses of tourism arrivals and arrivals by purpose of visit: the Singapore experience Journal of Travel Research 43 (1): 57-66.

UNWTO 2015: Tourism Highlights 2015 UNWTO, Madrid.

Volo, S.-Giambalvo, O. (2008): Tourism Statistics: Methodological Imperatives and Difficulties: The Case of Residential Tourism in Island Communities Current Issues in Tourism 11 (4): 369-380.

WynEN, J. (2013): Explaining travel distance during same-day visits Tourism Management 36: $133-140$

Yasin, M.-Alavi, J.-Sobral, F.-LisbOA, J. (2004). A shift-share analysis approach to understanding the dynamic of the Portuguese tourism market Journal of Travel and Tourism Marketing 17 (4): 11-22.

Yousuf, M.-BACKer, E. (2015): A content analysis of Visiting Friends and Relatives (VFR) travel research Journal of Hospitality and Tourism Management 25: 1-10. 